\title{
Similarity of particle-associated and free-living bacterial communities in northern San Francisco Bay, California
}

\author{
James T. Hollibaugh ${ }^{1, *}$, Patricia S. Wong ${ }^{1}$, Michael C. Murrell ${ }^{2, * *}$ \\ ${ }^{1}$ Department of Marine Sciences, University of Georgia, Athens, Georgia 30602-3636, USA \\ ${ }^{2}$ Institute of Marine Science, University of California, Santa Cruz, California 95064, USA
}

\begin{abstract}
We used denaturing gradient gel electrophoresis (DGGE) of 16S rDNA PCR amplicons to analyze the composition of Bacteria communities in samples collected during the summer, low flow season from northern San Francisco Bay, California. There were clear compositional differences in communities sampled at different locations in the Bay and at different times of the year. Particle-associated (attached) and free-living (free) bacteria in a given sample were generally more similar than communities in different samples. At times, the attached and free communities in a sample appeared identical, suggesting a fairly rapid exchange between them. The free-living community tended to be richer (more operational taxonomic units [OTU] per sample) than the attached community; however, the difference was not statistically significant. Richness declined through the summer. The richest samples were collected on the June cruise (51 OTU sample ${ }^{-1}$ ) while the least rich samples were collected on the Septemjer cruise (21 OTU sample ${ }^{-1}$ ). The number of distinct OTUs encountered in all samples from a cruise ranged from 61 (April) to 45 (October). The greatest number of unique OTUs (26) was found in Apr:l samples while the fewest (3) was found in September There was no consistent hierarchy of richness between samples. Sample groups representing location and size fractions contained from 55 to 61 different OTUs and from 8 to 18 unique (found only once) OTUs. An average of $23 \%$ of the OTUs from a given station and size fraction were unique while an average of $5.5 \%$ were found on all cruises. Ubiquitous OTUs (found at all stations) ranged from $34 \%$ (free-living, June) to $7 \%$ (free-living, August) of the distinct OTUs encountered on a given cruise. Our results suggest little difference in the biogeochemical role played by attached versus free bacteria in San Francisco Bay, particularly in the estuarine turbidity maximum. These results are generally consistent with our analyses of the metabolic potential of these communities.
\end{abstract}

KEY WORDS: Particles · Estuary · Bacteria · Community · San Francisco Bay - Diversity · Richness · DGGE

\section{INTRODUCTION}

The roles of particle-associated (attached) versus free-living (free) bacterial communities in planktonic environments, and the relationship between them, have long interested microbial ecologists. It has been argued (e.g. Stevenson 1978) that free bacteria are inactive because they require high substrate concentrations for growth. Particle microenvironments were

\footnotetext{
-E-mail: aquadoc@uga.edu

- Present address: Gulf Ecology Division, USEPA, 1 Sabine Island Drive, Gulf Breeze, Florida 32561, USA
}

thought to contain the elevated substrate concentrations assumed to be necessary for the growth of bacteria and thus, it was inferred, only bacteria closely associated with particles could be active. This view changed with the application of radiotracer methodology to microbial ecology when it was demonstrated that free bacteria could be as active as their attached counterparts (Azam \& Hodson 1977).

However, the controversy over the role of particles in microbial ecology remains. Some reports (Karl et al. 1988) suggest that particles are inimical to bacteria while others suggest that they act as refugia (Cho \& Azam 1988) or as sources for nutriment for the sur- 
rounding water (Smith et al. 1992). Colonization of large biogenic particles has been described and it is recognized that these have a successional series (Pomeroy \& Deibel 1980). Most detailed studies of the ecology of particles have focused on oceanic particles, especially marine snow, because they can be collected as discrete units and because they have been the focus of programs seeking to model vertical transport of carbon and other elements in the open ocean (Alldredge \& Silver 1988, Karl et al. 1988, Alldredge \& Jackson 1995). There has been less work on the community ecology of estuarine particles because of their small size, but they have been recognized as potentially important sites of biogeochemical transformations (Iriberri et al. 1987, Yoon \& Rosson 1990)

There are a number of reasons why the community ecology of large particles such as marine snow might be different from estuarine particles. Marine snow particles are primarily of biological origin-salp feces, larvacean houses, aggregated phytoplankton, etc. (Pomeroy \& Deibel 1980, Alldredge \& Silver 1988, Alldredge \& Gotschalk 1990, Alldredge 1995). They start out being composed of fairly labile organic matter and may even maintain moderate rates of primary production (Alldredge \& Cox 1982, Simon et al. 1990, Kaltenböch \& Herndl 1992). Estuarine particle composition is variable, but major components are detritus from terrestrial or estuarine higher plants, soil humics and peat, freshwater and marine phytoplankton and phytodetritus, and amorphous aggregations of suspended sediment, organic matter and bacteria. Estuarine particles, particularly those from macrotidal estuaries or estuaries with large river discharges, tend to contain a high percentage of inorganic material (Wienke \& Cloern 1987). Much of the organic matter that is present, at least initially, is derived from terrigenous organic matter, but this material is subsequently replaced by marine organic matter (Hackney \& Haines 1980, Incze et al. 1982, Mayer 1994a,b, Hedges \& Keil 1995, Keil et al. 1997), possibly as a result of microbial colonization and transformation. While sinking marine snow particles transport the associated microbial community away from the site of formation, the interactions between estuarine circulation, resuspension and sinking particles may benefit estuarine attached microbial communities by helping to retain populations in the estuary.

Bacterial association with particles may be passive or active, dynamic or stable. The similarity of attached and free communities in a water sample can provide insight into the exchange between these communities and into the partitioning of biogeochemical processes between them. Relationships between attached and free bacteria have only recently been explored in detail, though earlier papers explored this question using plate counts (e.g. Jannasch \& Jones 1959). DeLong et al. (1993) and Weiss et al. (1996) compared the composition of bacterial communities from marine snow and freshwater particles, respectively, with those from the surrounding water and found them to be quite different. Rath et al. (1998) extended DeLong et al.'s (1993) study to another class of marine snow particle. In contrast, Bidle \& Fletcher (1995) and Noble et al. (1997), who used 5S rRNA profiles to compare attached and free communities from Chesapeake Bay, found that the similarity of these fractions varied seasonally with only slight differences between them much of the summer. These differences mirror results of studies of metabolism where marine snow particles were found to be sites of metabolic processes not found in the water column (reviewed in Rath et al. 1998), while there appears to be little metabolic differentiation between free and attached communities in many estuaries (Iriberri et al. 1987, Hollibaugh \& Wong 1999, Murrell et al. 1999).

We report here a study of the similarity between attached and free bacterial communities in northern San Francisco Bay, a macrotidal estuary with high suspended particle loads. The general environmental setting of San Francisco Bay is described by papers in volumes edited by Conomos (1979a), Cloern \& Nichols (1985) and Hollibaugh (1996). San Francisco Bay bacterioplankton communities show a strong seasonal cycle of biomass and productivity and they respond strongly to phytoplankton blooms (Hollibaugh \& Wong 1996). Bacterial production exceeds phytoplankton primary production in the oligohaline reach of northern San Francisco Bay (Werner \& Hollibaugh 1993, Hollibaugh \& Wong 1996). Budgetary calculations (Jassby et al. 1993) show that allochthonous organic matter transported into this reach with freshwater inflow is quantitatively important to the $C$ budget. Although it is not known what fraction of this organic matter is readily labile, it appears to be important to bacterioplankton nutrition as the bacterioplankton community in this portion of the bay is metabolically distinct from communities in the southern reach of the bay or in nearby coastal waters (Hollibaugh 1988, 1994, Hollibaugh \& Wong 1992). Recent investigations have begun to address processing of this organic matter (Murrell 1998, Hollibaugh \& Wong 1999). Most bacteria in the oligohaline reach are attached and there appears to be some metabolic differentiation between attached and free communities (Hollibaugh \& Wong 1996, 1999, Murrell et al. 1999).

We examine the following 3 questions in this paper: Are attached bacterial communities in San Francisco Bay distinct from the free-living community in the same sample? Is community composition stable through time? Does community composition vary spa- 
tially? These studies were coordinated with other work on metabolic activity and organic matter characterization that is reported elsewhere (Murrell 1998, Murrell et al. 1999). We found that attached and free communities in samples from stations in the river and oligohaline reach were nearly indistinguishable most of the time, that there were large differences between the oceanic end-member and the freshwater end-member communities, and that the same organisms were sampled repeatedly, suggesting that community composition was stable for periods of at least months.

\section{METHODS}

Sampling locations and times. Samples were collected monthly during the spring and summer of 1996 (April through October, excluding May) on cruises of the RV 'Polaris' (USGS). We intentionally limited sampling to the summer period because northern San Francisco Bay is physically driven during the winter with low residence times, low biological activity and large suspended sediment loadings (Conomos 1979b, Krone 1979, Walters et al. 1985, Jassby et al. 1997). Collection began on the tail of a falling hydrograph and continued through the summer low-flow period (Fig, 1). The high flow pulse in late May was caused by a late storm and represents a basin-scale runoff event. Three sites were sampled (Fig. 1): Central San Francisco Bay near Angel Island (Stn 18, 'CB'), in the oligohaline reach, which is the region where the major estuarine turbidity maximum is found (surface salinity approximately 2 PSU, generally located in Suisun Bay, Stns 5 to 8, 'ETM'); and in freshwater in the Sacramento River near Rio Vista (Stns 657 or 649 , ' $R$ ' or 'River'). Surface water samples were collected by lowering a plastic bucket over the side.

Size fractionation. One sample $(0.5$ to 1 l) was gently filtered (gravity) through a $1.0 \mu \mathrm{m}$ pore size, $47 \mathrm{~mm}$ diameter Nuclepore filter. Material retained by the filter was designated as 'attached'. A second 1 to 2 I sample was filtered through a $47 \mathrm{~mm}$ diameter $\mathrm{GF} / \mathrm{C}$ glass fiber filter (nominal pore size $1.2 \mu \mathrm{m}$ ). Cells passing this filter were designated as 'free' and were collected from the filtrate in a Millipore Sterivex filter cartridge $(0.22 \mathrm{~mm}$ pore size) by pressure filtration $(400 \mathrm{kPa})$. Seawater remaining in the Sterivex filter cartridge was expelled with pressurized air (syringe), then $1.8 \mathrm{ml}$ of buffer (40 mM EDTA, $50 \mathrm{mM}$ Tris, $\mathrm{pH} 8.3$, and $0.75 \mathrm{M}$ sucrose) was added to the cartridge. The filters were capped and frozen at $-20^{\circ} \mathrm{C}$ until processed.

Although filter pore sizes overlap slightly and their filtration characteristics differ, we used the glass fiber filter to remove attached bacteria from free bacteria rather than a $1.0 \mu \mathrm{m}$ pore size polycarbonate filter because they pass a larger volume of water before clogging. As an extra precaution against clogging, the glass fiber filter was changed when flow slowed appreciably. The overlap might have decreased the apparent similarity of the free and attached communities slightly; however, we believe that this artifact is negligible based on results of other experiments (Hollibaugh unpubl. data).

DNA extraction and polymerase chain reaction (PCR)/ denaturing gradient gel electrophoresis (DGGE). DNA was extracted from the filters and used as the template for PCR (Saiki et al. 1988) amplification of a ca 200 bp region of the $16 \mathrm{~S}$ rRNA gene. The mixed PCR product was resolved using DGGE. The procedures we used were essentially as described in detail in Murray et al. (1996) or Ferrari \& Hollibaugh (1999).

Briefly, material retained by filters was digested with lysozyme, proteinase $\mathrm{K}$ and $1 \% \mathrm{SDS}$ at $60^{\circ} \mathrm{C}$. The crude extract was purified by phenol/chloroform extraction and ultrafiltration (Centricon) or ethanol precipitation. PCR used 1 to $10 \mathrm{ng}$ of purified DNA as
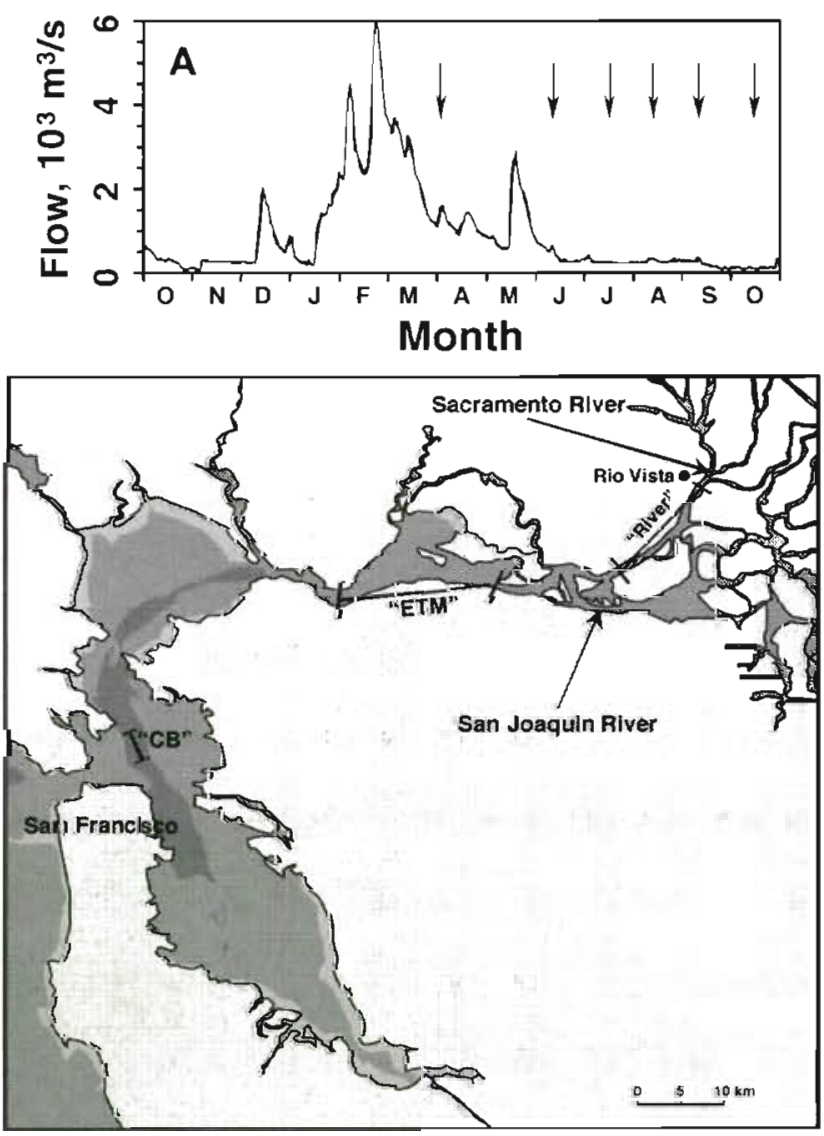

Fig. 1. (A) Freshwater flow into northern San Francisco Bay during the study period (DAYFLOW estimates courtesy State of California Department of Water Resources). Arrows denote sampling dates. (B) Locations sampled 
template and Taq polymerase with 17 mer primers: positions 341 to 358 (primer 341f, Bacteria); and 517 to 534 (primer 534r, Universal) in the Escheria coligene. These primers flank one of the hypervariable regions of the $16 \mathrm{~S}$ rRNA gene (the variable 3 or v 3 region) and amplify the $16 \mathrm{~S}$ rRNA gene of most species of Bacteria (Muyzer et al. 1993, Murray 1994). A 40 bp GC clamp was added to the $341 \mathrm{f}$ primer to improve DGGE resolution (Myers et al. 1985, 1987). PCR used the 'touchdown' and 'hot-start' protocols. PCR reactions (100 $\mu$ l) were run for 30 cycles.

Extraction blanks served as negative PCR controls. Genomic DNA from Clostridium perfringens (SIGMA Genomic Ultra Pure, No. D5139) or Bacillus thuringiensis (SIGMA High Molecular Weight, No. D3171) was used as a positive PCR control and as a DGGE standard. These standards were chosen because they were readily and universally available, facilitating comparisons between investigators; and because their v3 rDNA PCR products had high melting points and thus traveled most of the length of the gel before denaturing. This allowed us to normalize gel images (see below) without having to extrapolate greatly beyond standard bands.

DGGE was performed using $6.5 \%$ acrylamide gels containing a 40 to $70 \%$ gradient of deionized formamide/urea. Electrophoresis was performed at $60^{\circ} \mathrm{C}$ for $15 \mathrm{~h}$ at $75 \mathrm{~V}$ using a CBS Scientific DGGE apparatus (gel format: $14.5 \mathrm{~cm}$ wide $\times 20 \mathrm{~cm}$ long $\times 0.75 \mathrm{~mm}$ thick). Approximately $750 \mathrm{ng}$ of PCR product was concentrated by ethanol precipitation and loaded onto each lane. Standards were run in at least 3 lanes (sides and middle) of every gel.

DGGE gels were stained with ethidium bromide. Gel images were displayed and recorded using a UVP GDS 7500 Gel Documentation System. The images (640 wide by 480 pixels along lanes, 256 grayscale) were adjusted for brightness and contrast and viewed at different exposure lengths to adjust for differences in staining intensity and properties of the banding pattern, then recorded digitally.

Tears or staining blotches compromised the images of some lanes in some gels. In addition, some lanes received lower DNA loadings than desirable for clear resolution of banding patterns. Only lanes that were uniformly stained and had clear bands were selected for subsequent image analysis. For lanes that were not acceptable, a second portion of the concentrated PCR product was run on another gel or, if necessary, the whole process was repeated until an acceptable image was obtained for that sample.

Data analysis. Gel images recorded by the UVP system were inverted (to give dark bands on a light background) then processed and analyzed using BioRad's Molecular Analyst-Fingerprint Plus program version
1.0 (which appears to us to be the same as GelCompare, which is marketed by Applied Maths in Europe). Images were cropped (ca $90 \%$ of the original length dimension, ca $50 \%$ of the original width dimension) to include the top of the gel and all visible bands. Band intensities were averaged over 8 pixels across each lane (ca $50 \%$ of lane width) and rescaled against the highest and lowest intensities in the lane. We rescaled band intensities to correct for lane-to-lane and gel-togel variations in overall intensity due to differences in staining or in the amount of PCR product loaded in a lane. The resulting densitometric curves were stored as sets of paired position and intensity values.

Electropherograms were then normalized to a universal standard (an image of a standard lane recorded earlier). The upper edge of the gel (bottom of the loading well) was used as one reference point and the positions of major bands in standards were used as additional reference points. The program then used a linear interpolation based on the discrepancy between the positions of these reference points in the gel being analyzed and the corresponding reference points in the universal standard to stretch or shrink the gel image so that the bottoms of the wells and the standard bands all lined up with the corresponding markers in the universal standard.

When needed, additional processing using markers internal to sample lanes (distinctive bands shared by a number of samples) was used to correct for gel distortion. We minimized application of this processing step because it requires an a priori assumption that the bands being aligned represent the same sequence. We have verified this assumption on a limited number of samples by sequencing DNA in the bands, but we also found instances where the sequence of bands with very similar positions in a gel differed by $17 \mathrm{bp}$. Once normalized, a non-linear background subtraction (rolling ball algorithm) was performed. The final length of the normalized electropherogram and associated densitometric curve was 450 points.

Pairs of samples were compared using point-bypoint regressions of the rescaled, normalized densitometric curves (regression-based similarity analysis). This approach used the set of pairs of intensity values $\left(y_{x a}, y_{x b}\right)$ for each position $(x)$ on densitometric curves a and $b$ to calculate a Pearson product-moment correlation coefficient for that pair of curves. We limited the calculation to data from the middle of densitometric curves (between positions 50-100 and 350-400, depending on the sample set being compared) to avoid spurious correlations caused by large envelopes of material often seen at the beginning and ends of the electropherograms (Fig. 2). The matrix of correlation coefficients thus obtained was then used with cluster analysis (UPGMA) to generate a similarity dendro- 


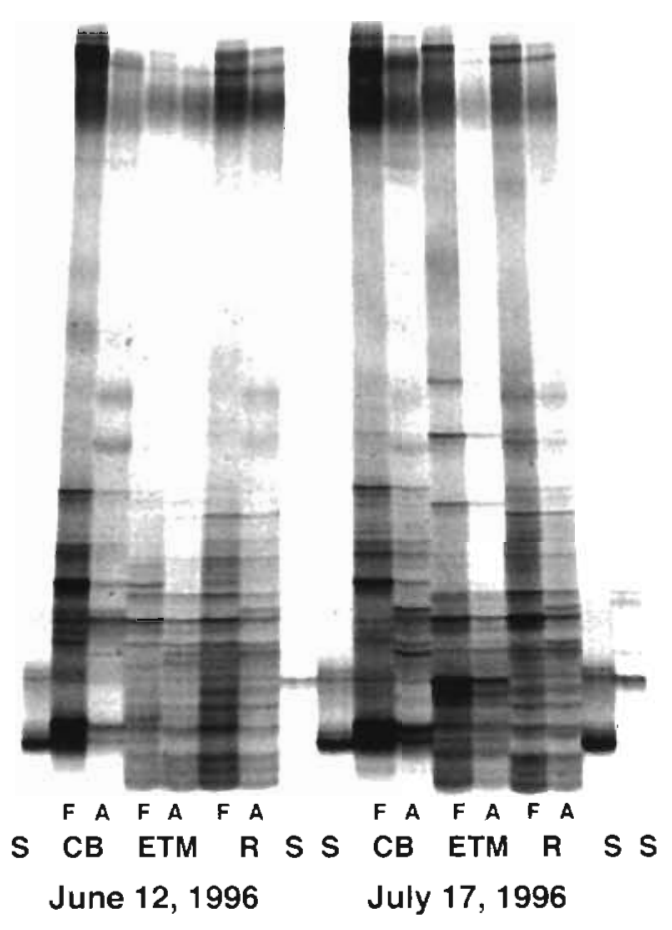

Fig. 2. Denaturing gradient gel electrophoretic resolution of v3 (341 to 534 Escherichia coli) rDNA PCR products of mixed template amplifications from samples collected in San Francisco Bay on 12 June and 17 July 1996. Lane designations are: $\mathrm{F}=$ free-living bacteria; $\mathrm{A}=$ attached or particle-associated bacteria; $\mathrm{S}=$ standards (Bacillus thuringiensis in the first lane from the left, Clostridium perfringens is the other standard) $\mathrm{CB}=$ Central Bay; ETM = estuarine turbidity maximum; $\mathrm{R}=$ River

gram. This analysis makes no assumptions regarding the significance of band intensity or position, focusing rather on the overall shape of the densitometric curves being compared. Previous work (Ferrari \& Hollibaugh 1999) demonstrated that this approach was more robust than using the position and intensity of individual bands to compare gels.

We also used the program to identify distinct bands so that we could compare the number of bands (operational taxonomic units [OTU]) in samples and examine the spatial and temporal variation in the distribution of specific OTUs. We set the program to identify only bands with areas $\geq 0.5 \%$ of the total area under the densitometric curve and heights $\geq 1 \%$ above the local background. We then manually edited the band (peak) calls for each lane, adding peaks which the program missed (usually associated with the shoulder of larger peaks) or deleting spurious calls. We simply marked the location of the peaks and did not attempt to estimate their height or area. We included all bands that were distinct from the background: if they displayed a distinct peak in the densitometry curve for the lane; if visual examination of the gel image revealed that the band was continuous across the lane; and if the band contained at least 2 rows of pixels.

We then examined the spatial and temporal variation of community composition as follows. Subsets of samples were compared with the position tolerance set at $0.3 \%$ of the lane length (chosen by trial and error). At this setting, bands (OTUs) in different lanes (samples) with positions differing by more than $0.3 \%$ of the total length of the normalized lane, here 450 positions, would be scored as being distinct while bands whose positions differ by less than this would be scored as being the same OTU. The program then calculates a consensus position for the band and generates a table of consensus positions and intensities for all bands in the group of samples. This table was used to analyze the distribution (presence or absence) of specific OTUs in our samples.

\section{RESULTS}

Fig, 2 presents an example of the DNA banding patterns seen in these samples. Since each lane represents a different sample (either station, date or fraction - free vs attached), bands that are common to more than 1 lane indicate that that OTU was found in more than 1 sample (see for example the strong bands joining pairs of lanes near the middle of the July ETM samples). In general, the bands connect pairs of lanes representing free and attached fractions from a given sample, or both fractions from adjacent samples. Some of the OTUs also seem to be persistent: the fairly strong band near the middle of the lanes for the CB June sample is also seen in the July CB, for example. Sequence data obtained for matching pairs like these from other samples indicate that they probably represent the same organism, though this cannot be stated for certain until the bands of interest are sequenced (none of the bands in these samples have been sequenced). Only rarely (CB July attached fraction, for example) are bands unique to either the free or attached fraction.

Fig. 3 shows the dendrograms for sets of all of the samples collected on each of the cruises. With the exception of the April CB sample, the composition of the free and attached bacterial communities from a given station clustered at $>74 \%$ similarity and was as high as $97 \%$. In another experiment (not shown) 5 replicates of the same sample that had been filtered, extracted, and amplified separately and run on the same DGGE gel clustered at $95 \%$ similarity. Free and attached bacteria from the same sample were paired as nearest neighbors in 11 of 18 samples collected on the 6 cruises. The analysis always paired free and attached bacteria from CB samples as nearest neigh- 


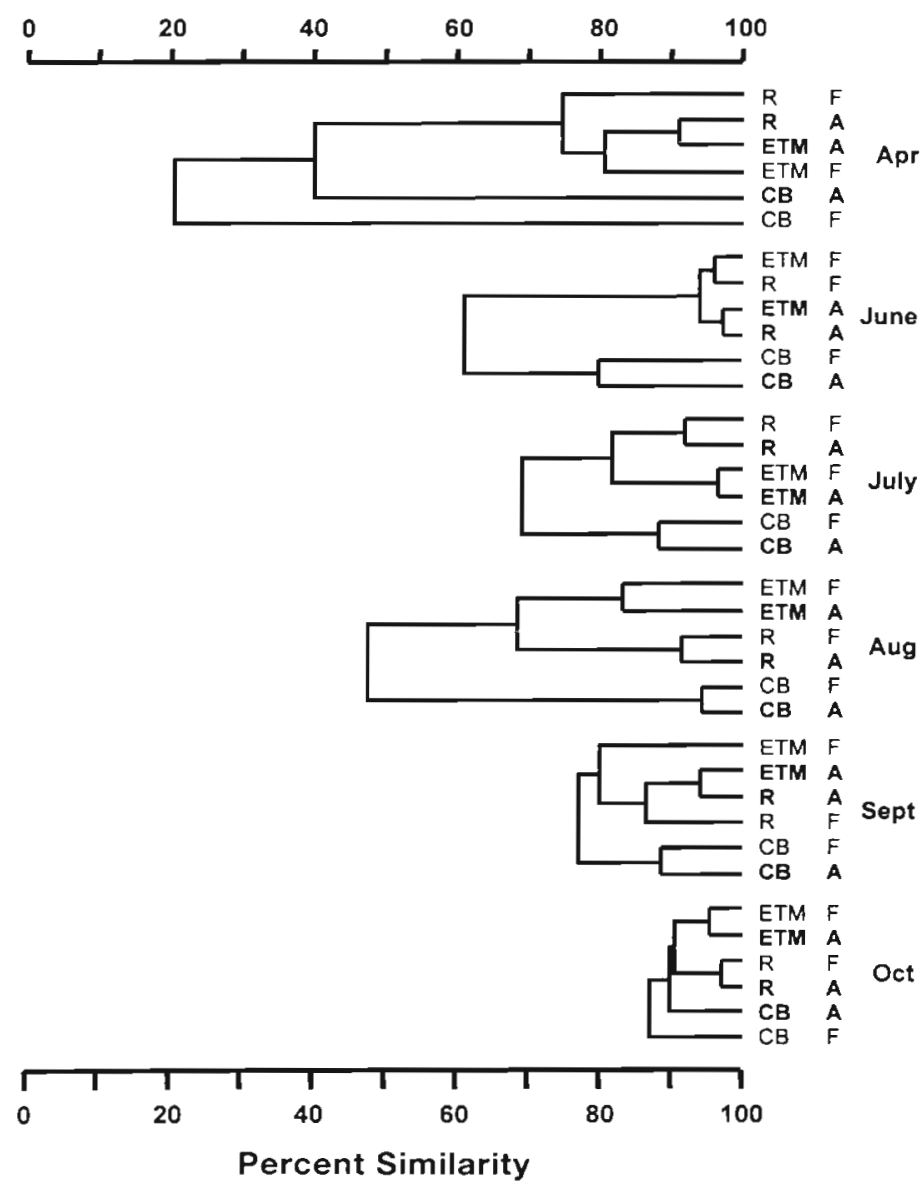

Fig. 3. Month-by-month analysis of the similarity of PCR/DGGE profiles of samples collected on 1996 cruises to northern San Francisco Bay. Abbreviations as in Fig. 2

bors and samples from the river and the ETM were more similar to each other than to CB samples. Free and attached bacteria in samples from ETM and River stations clustered by size fraction (free or attached), rather than by station, on 3 of the 6 cruises (April, June and September). Samples collected at different stations on a cruise generally became more similar to each other as the season progressed (Fig. 3).

We also performed the cluster analysis with all of the samples included (rather than month by month, which constrains the analysis). The dendrogram from this analysis is presented in Fig. 4. The greatest similarities were generally between free and attached fractions from a given sample. All of the September and October samples clustered together at 79 and $88 \%$ similarity, respectively, while June, July and August samples did not cluster together. April samples were the least similar to other samples and to each other. April River and ETM samples clustered together at $73.4 \%$ similarity, while April CB fractions only clustered at $19.9 \%$ similarity.
Community richness, defined here as the number of OTUs (different or distinct bands) in a lane, ranged from 21 to 51 OTU sample ${ }^{-1}$ with a mean of 32.9. Regression analysis indicated that free communities tended to be richer than attached communities from the same sample (Fig. 5, slope $\left.=0.67, r^{2}=0.54\right)$; however, the slope was not statistically different from $1(\mathrm{p}>0.05)$. There appeared to be a seasonal decline in richness (Fig. 6) which paralleled the seasonal decline in the number of distinct OTUs observed on each cruise (Table 1). The greatest richness was observed in the June samples, while the least rich samples were collected in September. There was no consistent hierarchy of richness in these samples (Fig. 6).

Table 1 gives the numbers of distinct O'TUs associated with groups (free or attached fractions at a particular station through time, or all stations and fractions on a given cruise). All of our samples combined contained a total of 80 distinct OTUs. From 55 to 61 OTUs were found in the groups of samples representing station and fraction combinations over all cruises (Table 1). The number of distinct OTUs in all of the samples collected on a cruise ranged from 45 to 61 , with the fewest found in September and October samples. The greatest number of unique (found only once) OTUs was encountered in April samples while the September samples had the fewest (Table 1). Fig. 7 shows the distribution of persistent OTUs (defined here as those found on more than 1 cruise, but not necessarily on successive cruises) by station and sample type through time. The number of persistent OTUs in a group declined from $31 \%$ (average 23\%) that were encountered on only 1 cruise to a maximum of $7.3 \%$ (average $5.5 \%$ ) that were found on all 6 cruises. There was no obvious relationship between persistence of OTUs and sample group (Fig. 7). Inspection of the data (not shown) revealed no obvious pattern in the presence or absence of OTUs. Specifically, there was no obvious reason for the increase in the percentage of OTUs present on 4 different months, nor was there any evidence for runs of persistent OTUs consistent with seasonal succession (i.e. OTUs present April to June that were absent July to October). Rather, the replacements seemed random.

The occurrence of ubiquitous OTUs (defined here as those found at all stations on a given cruise) ranged from $34 \%$ (June) to $7 \%$ (August) of the number of distinct OTUs found in all samples collected on a particular cruise (Fig. 8). There was no obvious relationship between the frequency that ubiquitous OTUs were found and sample type (attached vs free). 


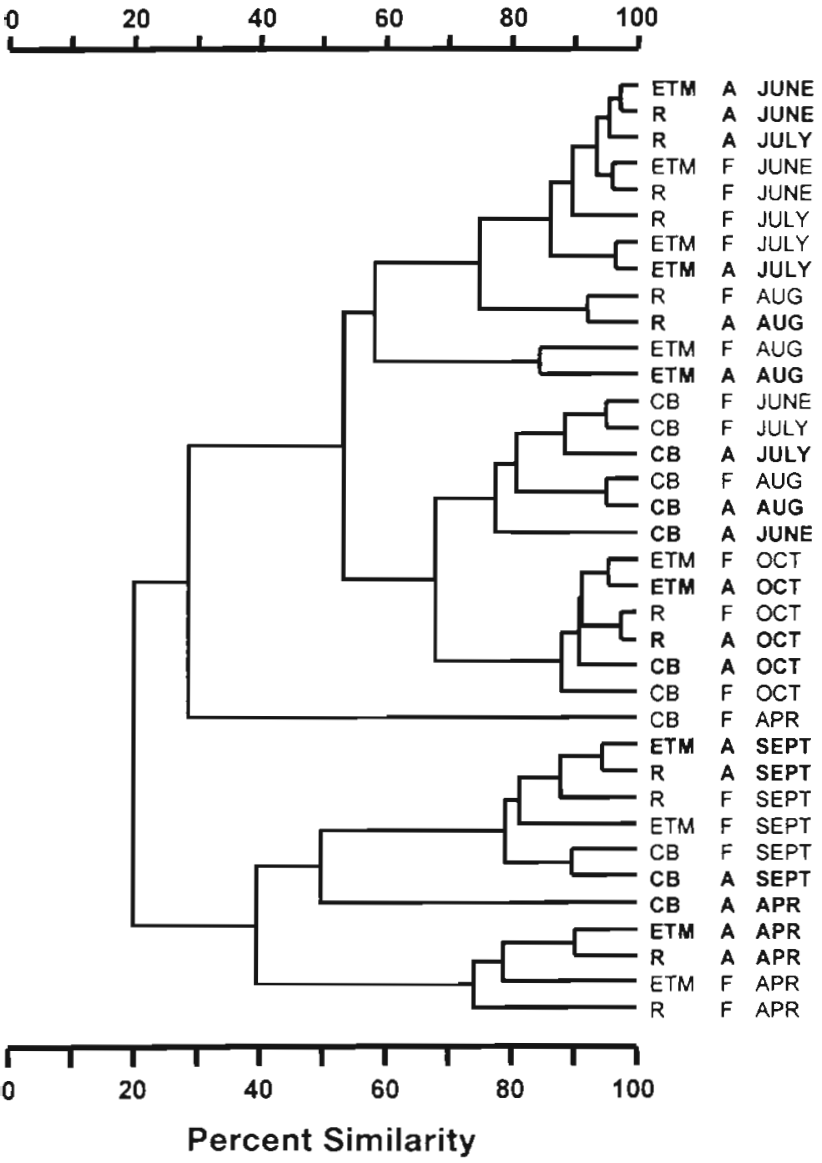

Fig. 4. Analysis of the similarity of PCR/DGGE profiles of all samples collected in northern San Francisco Bay during 1996 combined. Abbreviations as in Fig. 2

\section{DISCUSSION}

The results of our analyses indicate that there is little difference between attached and free bacterial communities in samples from northern San Francisco Bay, particularly at the River and ETM stations. The difference between these communities was greater in the $\mathrm{CB}$, suggesting a possible shift in the ecological relationship between free and attached communities.

The similarity between free and attached bacteria in northern San Francisco Bay resembles patterns found in a comparable study of Chesapeake Bay communities by Noble et al. (1997). These results contrast with studies of marine snow (for example DeLong et al. 1993) where attached and free communities were found to be very different. Differences in the biases and limitations of the methodologies employed in these studies may have contributed to the differences in their results, particularly with regard to the total number of OTUs observed. As discussed in the 'Introduction' of this paper, differences in particle origin and composition between estuarine particles versus marine snow are probably more important determinants of the similarity or differences of attached versus free communities.

The dissimilarity of attached versus free communities at the CB station suggests that the ecology of these particles is more like that of marine snow. Analyses of their composition and of other properties of the bacterial communities associated with them (ectoenzyme activity, substrate utilization profiles) reported in Murrell (1998) and Murrell et al. (1999) support this conclusion. In general terms, $\mathrm{CB}$ particles appear to be more biogenic than particles from the River or ETM stations: they have higher chlorophyll/POC and POC/ SPM ratios (Wienke \& Cloern 1987, Cloern et al. 1995 , Murrell 1998).

The similarity of attached and free communities in the ETM suggests that either the particle environment is similar to the bulk phase water, i.e. that the particles are essentially inert, or that there is relatively rapid exchange between attached and free bacterial communities. There are indications of metabolic divergence of these communities, suggesting active selection for specific types of organisms; however, the divergence is not great. Under epifluorescence microscopy, the morphological characteristics of attached cells are indistinguishable from free cells in the same sample. Harvey (pers. comm.) found that the mean size and cell-specific glucose incorporation rate was greater for attached cells than for free-living cells in samples from the ETM region; however, there was no difference in South San Francisco Bay samples. Hollibaugh \& Wong (1999) found no difference in cell-specific L-leucine incorporation by attached versus free

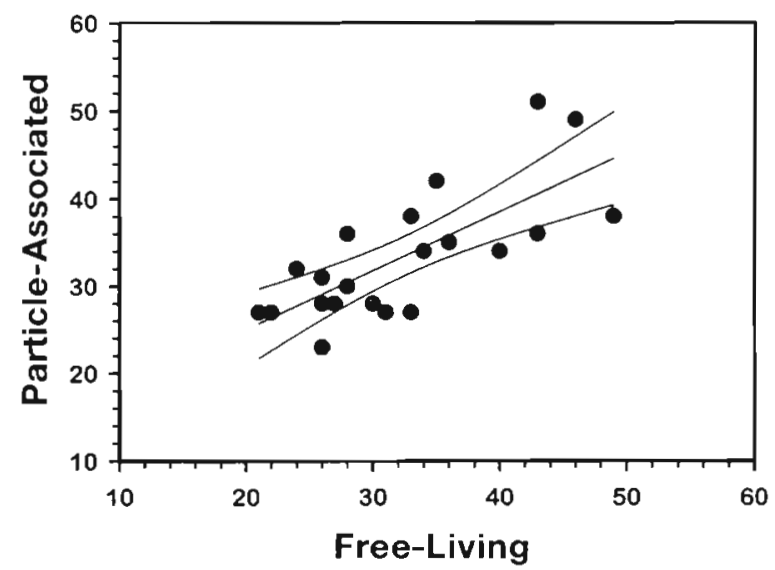

Fig. 5. Comparison of the richness of attached and free communities in San Francisco Bay samples. Units are the number of operational taxonomic units (OTUs; bands in DGGE gels) per sample. Lines are the least squares linear regression and $95 \%$ confidence belts 
Table 1. Occurrence of unique operational taxonomic units (OTUs) in northern San Francisco Bay samples. The column headed 'Number of distinct OTUs found on all cruises' gives the total number of different OTUs found in a given fraction from a given station on all cruises. The columns headed by months give the number of unique OTUs found in a given fraction (free $[\mathrm{F}]$ or attached $[\mathrm{A}]$ ) at a given station only on that cruise $e_{i}$ these are totaled by station/fraction and cruise in the column and row headed 'Total'. The row headed 'Number of distinct OTUs found at all stations' gives the number of different OTUs found in all samples collected on a given cruise. $\mathrm{CB}=$ Central Bay; $\mathrm{ETM}=$ estuarine turbidity maximum

\begin{tabular}{|lccccccccc|}
\hline \multicolumn{1}{c}{$\begin{array}{c}\text { No. of distinct } \\
\text { OTUs found } \\
\text { on all cruises }\end{array}$} & A.pr & Jun & Jul & Junique OTUs & Aug & Sep & Total \\
\hline CB F & 55 & 4 & 1 & 1 & 1 & 1 & 0 & 8 \\
CB A & 56 & 2 & 4 & 1 & 4 & 0 & 1 & 12 \\
ETM F & 59 & 6 & 1 & 0 & 5 & 1 & 5 & 18 \\
ETM A & 61 & 4 & 2 & 4 & 2 & 1 & 3 & 16 \\
River >1 & 60 & 5 & 0 & 4 & 3 & 0 & 2 & 14 \\
River <1 & 58 & 5 & 2 & 0 & 4 & 0 & 1 & 12 \\
Total & 26 & 10 & 10 & 19 & 3 & 12 & \\
No. of distinct & 61 & 56 & 55 & 60 & 46 & 45 & \\
OTUs found & & & & & & & \\
at all stations & & & & & & & & & \\
\hline
\end{tabular}

communities from the ETM; however, they noted that a metabolism index based on thymidine incorporation (Hollibaugh 1994) indicated some metabolic differentiation of these communities. Following Garland \& Mills (1991), we used BIOLOG plates to assess the metabolic diversity of these communities and found them to be different (Hollibaugh unpubl. data). Finally, Murrell et al. (1999) found higher per cell ectoenzyme activity in attached communities.

This evidence suggests that the particle microenvironment is different enough from bulk-phase water to lead eventually to metabolic differentiation of attached communities, and thus that the phylogenetic composition of these communities should eventually diverge. However, the metabolic divergence is not extreme and, as discussed above, these 2 communities are very similar, especially in ETM and River samples. This suggests rapid exchange of organisms, with residence times in either community short enough to prevent substantial divergence of phylogenetic composition. Assuming that ETM particles settle to the bottom regularly as current models suggest (Burau \& Schoelhammer pers. comm.), rather than being continuously held in suspension, these results also suggest that particles do not reside in the sediment long enough for redox changes, etc. to affect community composition.

As a rough indication of this time scale, the mean population doubling time for bacterioplankton in this area of San Francisco Bay is $0.74 \mathrm{~d}$ (calculated from data given in Hollibaugh \& Wong 1996); thus the time that it would take for an organism initially present at $10 \%$ relative abundance to become dominant (78\% relative abundance assuming no change in the abundance of other bacteria) is 5 doublings or $3.7 \mathrm{~d}$. Exchange between attached and free communities must occur at a time scale shorter than this to avoid compositional (and pronounced metabolic) divergence. By comparison, hydraulic residence times in this region of San Francisco Bay were of the order of a month during the summer, low flow season we sampled (Walters et al. 1985), while particle residence times are longer still (Krone 1979).

We have also used the banding patterns in our gels to compare the richness of the communities we sampled. This interpretation must be treated with caution because a number of factors associated with the analysis influence the apparent richness (discussed in detail in Ferrari \& Hollibaugh 1999). One of the simplest of these is the technology used to analyze gel images. We used a program specifically designed for analyzing banding patterns in gels. This program, among other things, subtracts background, displays the densitometric curve parallel to the lane image and has the ability to magnify portions of the digitized lane image to facilitate visual detection and editing of banding patterns. These features facilitate detection of faint and overlapping bands and may account for the greater richness we report (21 to 51, mean 32.9 OTU sample $^{-1}$ ) when compared to Murray et al.'s (1996) analysis of samples from the same area (22 to 31 , mean 26 OTU sample ${ }^{-1}$ ).

Another factor that may influence our analysis of richness is the region of the 16S rRNA gene we exam-

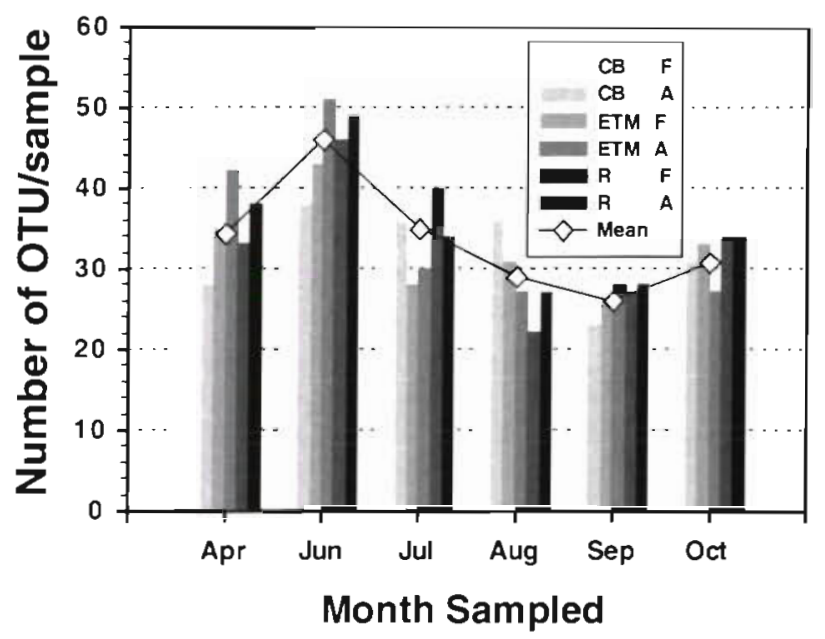

Fig. 6. Temporal variation in the richness of San Francisco Bay bacterial communities. Abbreviations as in Fig. 2 


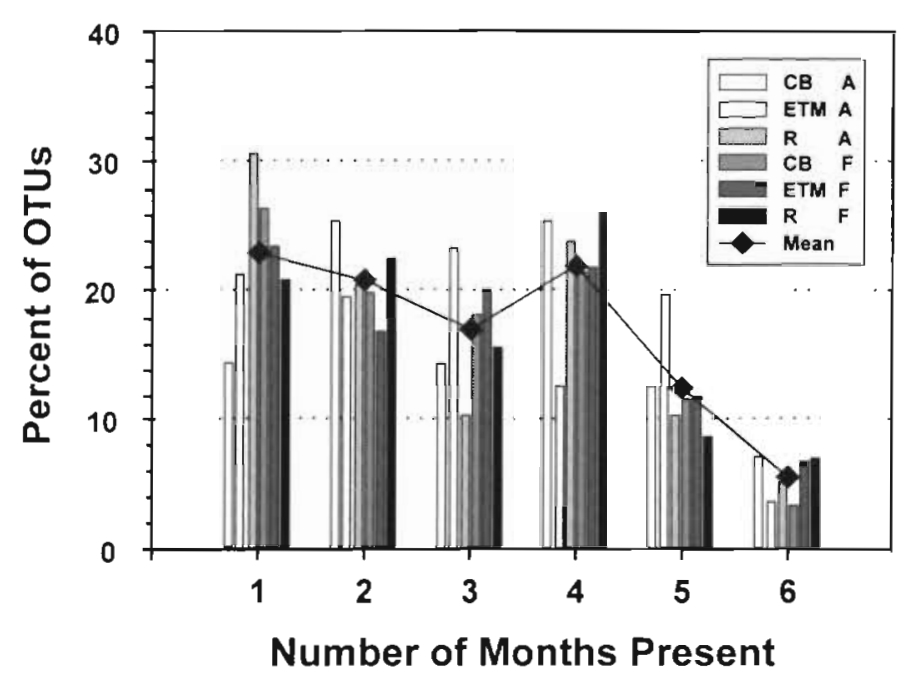

Fig. 7. Persistence of OTUs in San Francisco Bay samples. The percentage of all of the different OTUs found in a specific sample type (for example the $\mathrm{CB}$ attached assemblage, CB A) during the study (ordinate) that were found on $1,2,3$, etc. not-necessarily-sequential cruises (abscissa)

ined. Murray (1994) found that the lengths of fragments amplified by the $341 \mathrm{f} / 534 \mathrm{r}$ primer set from samples collected in the study area ranged from 169 to $234 \mathrm{bp}$, including the primer sites ( $34 \mathrm{bp}$ ). Thus, we are basing our assessment of richness on an analysis of roughly $10 \%$ of the $16 \mathrm{~S}$ rRNA gene: sequence variation outside of the region amplified by these primers will not be detected in our analysis. The v3 region encompassed by these primers accounts for a disproportionately large portion of all of the variability in the $16 \mathrm{~S}$ gene (Barry et al. 1990), but not for all of it.

PCR biases may also influence the apparent richness through preferential amplification of some sequences (Reysenbach et al. 1992, Suzuki \& Giovannoni 1996) or multiple gene copies (Farrelly et al. 1995); however proof-of-concept experiments we (Murray 1994) and Muyzer et al. (1993) performed suggested that the analysis is not excessively selective and that it is at least semi-quantitative. This conclusion is also supported by more recent work (Santegoeds et al. 1996, Riemann et al. 1998). Regardless of PCR biases, DNA from cells that are recalcitrant to extraction will be under-represented in the PCR template and thus in the PCR product resolved by DGGE.

When screening isolates by PCR/DGGE, we have noticed a tendency for some sequences to form multiple bands, for example the $\mathrm{v} 3$ products from Bacillus thuringiensis and Clostridium perfringens that we use as positive PCR controls and marker sequences (Fig 2). This is common, but does not happen with all sequences. The banding pattern for a given isolate is also extremely repeatable, as indicated by our examination of a few hundred positive PCR controls.

We do not fully understand why some sequences generate multiple bands in DGGE. Our analysis indicates that DNA sequences in the different bands are the same, suggesting that multiple bands arise somehow as a result of the secondary conformation of these sequences. This does not appear to be a serious problem with mixed template amplifications of natural samples, as similar sequencing efforts reveal that different bands in the same lane represent different sequences (Hollibaugh unpubl. data). Furthermore, Santegoeds et al. (1996) found a good relationship between the number of bands in a DGGE analysis and the number of isolates obtained by extensive culturing. If multiple bands are generated for the same sequence in mixed template amplifications of natural samples, our band count would overestimate the richness of our samples. Since the banding pattern seems to be a unique and highly repeatable property of a given sequence, it would not affect our ability to compare the banding patterns, and thus similarity, of different samples.

With these caveats, there are a number of features of these distributions that warrant discussion. First, the numbers of OTUs from attached versus free communities at a particular station and time were not signifi-

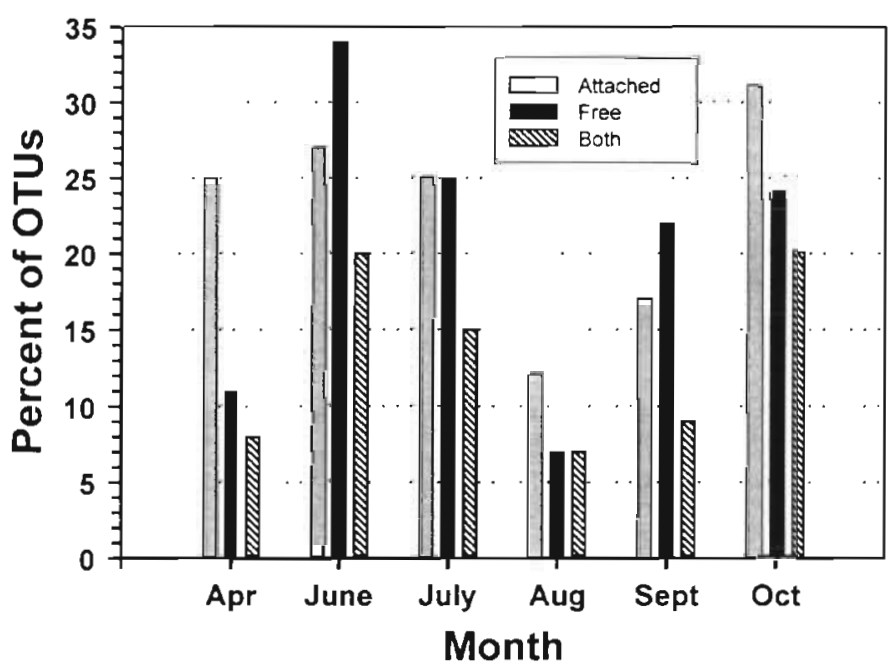

Fig. 8. Occurrence of ubiquitous OTUs (present at all stations on a cruise) as the percentage of total number of different OTUs collected in all samples on a cruise. Attached; percentage of OTUs ubiquitous in attached communities. Free: percentage of OTUs ubiquitous in free-living communities. Both: percentage of OTUs ubiquitous in both attached and free-living communities 
cantly different from each other (Fig. 5), though there were more OTUs in free than attached communities. This is consistent with regression-based similarity analysis (Figs. $3 \& 4$ ), which suggests little difference between these communities. This result also indicates that plastid sequences derived from eucaryotes, which would have been removed from the free-living community by $G F / C$ filtration, did not interfere with the PCR/DGGE analysis. This was a concern because Murray's (1994) analysis of the specificity of the primers we used indicated that they could amplify plastid sequences and we have found bands from chloroplast sequences in gels of samples from other sites.

Second, the temporal variation in the number of OTÚs per sample is surprisingiy similar to the temporal variation in ectoenzyme activity found in these same samples (Murrell 1998, Murrell et al. 1999), with higher activities found in May and June and lowest activities in August and September. The increase in overall similarity (Fig. 3) and decrease in richness (Fig. 6) at a given station through time is generally consistent with this pattern as well. While other microbiological properties showed similar trends (Murrell 1998), the relationship with ectoenzyme activity is clearest. It is unclear whether elevated ectoenzyme activity is a cause, a consequence of, or completely unrelated to elevated community richness; however, this relationship suggests an interesting area for further work.

Third, as reported by Murray et al. (1996), some OTUs persisted throughout the sampling period. Others were found repeatedly or at more than 1 station. This suggests that the bacterial communities of northern San Francisco Bay are relatively stable through time. We saw no obvious patterns or runs of OTUs that might suggest an ordered seasonal replacement of OTUs; rather our analysis suggested random replacement of a portion of the population each month. Part of the explanation for this may be related to our decision to sample only during summer, low flow conditions to emphasize the effects of biological over physical variability in our study. We missed major seasonal transitions because we intentionally restricted our sampling to the most stable portion of the seasonal cycle. The apparently random appearances and disappearances of OTUs might thus represent community responses to biological or physical processes with time scales shorter than our sampling interval, similar to replacement of coastal populations reported by Rehnstam et al. (1993).

The high outflow event near the end of May (Fig. 1) may be an example of this kind of event. The event may have reset community composition in northern San Francisco Bay by flushing out the communities established during declining flows in April and early May. If a new community became established in June, the remaining 4 mo (July, August, September and October) represented the stable part of the summer and shared more OTUs than April and June (recovering from flood). Although inspection of the temporal distribution of OTUs did not reveal any obvious runs to support this speculation, it does provide a possible explanation for the relatively flat curve in persistence from 1 to $4 \mathrm{mo}$, the peak at $4 \mathrm{mo}$ and the rapid drop in persistence over 5 and 6 mo (Fig. 7).

Finally, our results also demonstrate changes in the composition of bacterial communities along the estuarine gradient and support the conclusions of an earlier study of San Francisco Bay populations (Murray et al. 1996). These changes may be related to environmental preferences or tolerances (e.g. salinity, temperature) or changes in organic matter composition and availability. Our sampling program was designed to examine interactions between particle-associated and free-living populations, rather than to resolve changes along the gradient. As a result we do not have enough samples to elucidate environmental preferences of specific OTUs.

It was somewhat surprising to find the same OTUs present in both the freshwater and marine ends of the estuarine gradient, as recent results (Weiss et al. 1996, Gonzalez \& Moran 1997) suggest significant differences in the composition of freshwater versus marine bacterial communities. It is possible that these OTUs are not the same but rather represent DNAs with different sequences but similar DGGE migration characteristics, as we have seen this in other samples. It is also possible that they represent freshwater organisms that are able to persist in seawater for extended periods of time or that they are resting stages or recalcitrant forms that are not lost to normal population turnover (grazing, viral lysis, etc.) and thus that do not have to be actively growing for their genetic material to persist. This question could be resolved with more directed analysis of these samples or with additional field experiments.

\section{CONCLUSIONS}

Our analysis of the free and attached communities of microorganisms in our samples suggests that these 2 fractions function as 1 ecological and biogeochemical unit with relatively rapid exchange between them. This differs from marine snow where there are distinct compositional and metabolic differences between the 2 communities. San Francisco Bay particles may represent one extreme on a spectrum ranging from particles in turbid estuaries with high inorganic content and relatively low concentrations of labile organic matter to 
biogenic and labile marine snow particles. Other particle-rich estuarine systems such Chesapeake Bay or the Columbia River estuary may lie between these extremes as there appears to be greater differentiation between the free and attached communities in these estuaries than in San Francisco Bay (Bidle \& Fletcher 1995, Crump \& Baross 1996, Noble et al. 1997, Crump et al. 1998), but less than in marine snow (DeLong et al. 1993, Weiss et al. 1996, Rath et al. 1998). This differentiation probably ultimately depends on the availability in the particle microenvironment of labile organic matter, which in estuaries is related to terrigenous inputs and the overall productivity of the system and in marine snow to the age and origin of the snow particle.

Acknowledgements. The authors would like to thank the US Geological Survey's San Francisco Bay Project for logistic support during this study. We would especially like to thank the captain and crew of the RV 'Polaris' for their help on the cruises. Drs F. Azam and W. J. Wiebe provided insightful comments on an earlier version of the manuscript. This research was funded by NSF OCE 93-15639 and by contract B-80883 from the State of California, Department of Water Resources to J.T.H. We would like to thank the Interagency Ecological Program, especially Dr Randall Brown, for their continued support of our work on San Francisco Bay

\section{LITERATURE CITED}

Alldredge AL (1995) Mass aggregation of diatom blooms: insights from a mesocosm study. Deep-Sea Res II 42:9-28

Alldredge AL, Cox JL (1982) Primary productivity and chemical composition of marine snow in surface waters of the Southern California Bight. J Mar Res 40:517-527

Alldredge AL, Gotschalk CC (1990) The relative contribution of marine snow of different origins to biological processes in coastal waters. Cont Shelf Res 10:41-58

Alldredge AL, Jackson GA (1995) Topical studies in oceanography: aggregation. Deep-Sea Res II 42:1-273

Alldredge AL, Silver MW (1988) Characteristics, dynamics and significance of marine snow. Prog Oceanogr 20:41-82

Azam F, Hodson RE (1977) Size distribution and activity of marine microheterotrophs. Limnol Oceanogr 22:492-501

Barry T, Powell R, Gannon R (1990) A general method to generate DNA probes for microorganisms. Bio-Technol 8: $233-236$

Bidle KD, Fletcher M (1995) Comparison of free-living and particle-associated bacterial communities in the Chesapeake Bay by stable low-molecular-weight RNA analysis Appl Environ Microbiol 61:944-952

Cho BC, Azam F (1988) Major role of bacteria in biogeochemical fluxes in the ocean's interior. Nature 332:441-443

Cloern JE, Nichols FH (1985) Temporal dynamics of an estuary: San Francisco Bay. Kluwer Academic, Norwell, MA, p 237

Cloern JE, Grenz C, Vidergar-Lucas L (1995) An empirical model of the phytoplankton chlorophyll:carbon ratio- the conversion factor between productivity and growth rate. Limnol Oceanogr 40:1313-1321

Conomos TJ (1979a) San Francisco Bay: the urbanized estuary. Pacific Division, AAAS, San Francisco, CA, p 679

Conomos TJ (1979b) Properties and circulation of San Fran- cisco Bay waters. In: Conomos TJ (ed) San Francisco Bay: the urbanized estuary. Pacific Division, AAAS, San Francisco, p 47-84

Crump BC, Baross JA (1996) Particle-attached bacteria and heterotrophic plankton associated with the Columbia River estuarine turbidity maxima. Mar Ecol Prog Ser 138: $265-273$

Crump BC, Baross JA, Simenstad CA (1998) Dominance of particle-attached bacteria in the Columbia River estuary, USA. Aquat Microb Ecol 14:7-18

DeLong E, Franks D, Alldredge A (1993) Phylogenetic diversity of aggregate-attached vs. free-living marine bacterial assemblages. Limnol Oceanogr 38:924-934

Farrelly V, Rainey FA, Stackebrandt E (1995) Effect of genome size and rrn gene copy number on PCR amplification of 16S rRNA genes from a mixture of bacterial species. Appl Environ Microbiol 61:2798-2801

Ferrari VC, Hollibaugh JT (1999) Distribution of microbial assemblages in the central Arctic Ocean basin studied by PCR/DGGE: analysis of a large data set. Hydrobiologia 401:55-68

Garland JL, Mills AL (1991) Classification and characterization of heterotrophic microbial populations on the basis of patterns of community-level sole-carbon-source utilization. Appl Environ Micrabiol 57:2351-2359

Gonzalez JM, Moran MA (1997) Numerical dominance of a group of marine bacteria in the a-subclass of the class Proteobacteria in coastal seawater. Appl Environ Microbiol $63: 4237-4242$

Hackney CT, Haines EB (1980) Stable carbon isotope composition of fauna and organic matter collected in a Mississippi estuary. Estuar Coast Mar Sci 10:703-708

Hedges JI, Keil RG (1995) Sedimentary organic matter preservation: an assessment and speculative synthesis. Mar Chem 49:81-115

Hollibaugh JT (1988) Limitations on the $\left[{ }^{3} \mathrm{H}\right]$ thymidine method for estimating bacterial productivity due to thymidine metabolism. Mar Ecol Prog Ser 43:19-30

Hollibaugh JT (1994) Relationship between thymidine metabolism, bacterioplankton community metabolic capabilities and sources of organic matter. Microb Ecol 28:117-131

Hollibaugh JT (1996) San Francisco Bay: the ecosystem. Pacific Division, AAAS, San Francisco, CA, p 542

Hollibaugh JT, Wong PS (1992) Ethanol extractable substrate pools and the incorporation of thymidine, L-leucine and other substrates by bacterioplankton. Can J Microbiol 38: $605-613$

Hollibaugh JT, Wong PS (1996) Distribution and activity of bacterioplankton in San Francisco Bay. In: Hollibaugh JT (ed) San Francisco Bay: the ecosystem. Pacific Division, AAAS, San Francisco, CA, p 263-288

Hollibaugh JT, Wong PS (1999) Microbial processes in the San Francisco Bay estuarine turbidity maximum. Estuaries 22:890-904

Incze LS, Mayer LM, Sherr EB, Macko SA (1982) Carbon inputs to bivalve mollusks: a comparison of two estuaries. Can J Fish Aquat Sci 39:1348-1352

Iriberri J, Unanue M, Barcina I, Egea L (1987) Seasonal variation in population density and heterotrophic activity of attached and free-living bacteria in coastal waters. Appl Environ Microbiol 53:2308-2314

Jannasch HW, Jones GE (1959) Bacterial populations in seawater as determined by different means of enumeration. Limnol Oceanogr 4:128-139

Jassby AD, Cloern JE, Powell TM (1993) Organic carbon sources and sinks in San Francisco Bay: variability induced by river flow. Mar Ecol Prog Ser 95:39-54 
Jassby AD, Cole BE, Cloern JE (1997) The design of sampling transects for characterizing water quality in estuaries. Estuar Coast Shelf Sci 45:285-302

Kaltenböck E, Herndl G (1992) Ecology of amorphous aggregates (marine snow) in the Northern Adriatic Sea. IV. Dissolved nutrients and the autotrophic community associated with marine snow. Mar Ecol Prog Ser 87:147-159

Karl DM, Knauer GA, Martin JH (1988) Downward flux of particulate organic matter in the ocean: a particle decomposition paradox. Nature 332:438-441

Keil RG, Mayer LM, Quay PD, Richey JE, Hedges JI (1997) Loss of organic matter from riverine particles in deltas. Geochim Cosmochim Acta 61:1507-1511

Krone RB (1979) Sedimentation in the San Francisco Bay system. In: Conomos TJ (ed) San Francisco Bay: the urbanized estuary. Pacific Division, AAAS, San Francisco, CA, p 85-96

Mayer LM (1994a) Relationships between mineral surfaces and organic carbon concentrations in soils and sediments. Chem Geol 114:347-363

Mayer LM (1994b) Surface area control of organic carbon accumulation in continental shelf sediments. Geochim Cosmochim Acta 58:1271-1284

Murray AE (1994) Community fingerprint analysis: a molecular method for studying marine bacterioplankton diversity biology. San Francisco State University, San Francisco, $\mathrm{CA}, \mathrm{p} 128$

Murray AE, Hollibaugh JT, Orrego C (1996) Phylogenetic composition of bacterioplankton from two California estuaries compared by denaturing gradient gel electrophoresis of 165 rDNA fragments. Appl Environ Microbiol 62 : $2676-2680$

Murrell MC (1998) Microbial processes and food web dynamics in a turbid estuary: northern San Francisco Bay, California, USA Biology. University of California, Santa Cruz CA, p 169

Murrell MC, Hollibaugh JT, Silver MW, Wong PS (1999) Bacterioplankton dynamics in northern San Francisco Bay: role of particle association and seasonal freshwater flow. Limnol Oceanogr 44:295-308

Muyzer G, Wall ECD, Uitterlinden AG (1993) Profiling of complex microbial populations by denaturing gradient gel electrophoresis of polymerase chain reaction-amplified genes coding for $16 \mathrm{~S}$ rDNA fragments. Appl Environ Microbiol 59:695-700

Myers RM, Fischer SG, Lerman LS, Maniatis T (1985) Nearly all single base substitutions in DNA fragments joined to a GC-clamp can be detected by denaturing gradient gel electrophoresis. Nucl Acids Res 13:3131-3145

Myers RM, Maniatis T, Lerman LS (1987) Detection and localization of single base changes by denaturating gradient gel electrophoresis. Methods Enzymol 155:501-527

Noble PA, Bidle KD, Fletcher M (1997) Natural microbial community compositions compared by a back-propagating neural network and cluster analysis of 5S rRNA. Appl

Editorial responsibility: Jed Fuhrman,

Los Angeles, California, USA
Environ Microbiol 63:1762-1770

Pomeroy LR, Deibel D (1980) Aggregation of organic matter by pelagic tunicates. Limnol Oceanogr 25:643-652

Rath J, Wu KY, Herndl GJ, DeLong EF (1998) High phylogenetic diversity in a marine-snow associated bacterial. assemblage. Aquat Microb Ecol 14:261-269

Rehnstam AS, Backman S, Smith DC, Azam F, Hagström £ (1993) Blooms of sequence-specific culturable bacteria in the sea. FEMS Microbiol Ecol 102:161-166

Reysenbach A, Giver LJ, Wickham GS, Pace N (1992) Differential amplification of rRNA genes by polymerase chain reaction. Appl Environ Microbiol 58:3417-3418

Riemann L, Fandino LB, Steward GF, Smith DC, Ducklow HW, Azam F (1998) Variability of bacterial community composition in the Arabian Sea during the 1995 JGOFS program. EOS 79:OS68

Saiki RK, Gelfand DH, Stoffel S, Scharf SJ, Higuchi R, Horn GT, Mullis KB, Erlich HA (1988) Primer-directed enzymatic amplification of DNA with o thermostabie DNA polymerase. Science 239:487-491

Santegoeds CM, Nold SC, Ward DM (1996) Denaturing gradient gel electrophoresis used to monitor the enrichment culture of aerobic chemoorganotrophic bacteria from a hot spring cyanobacterial mat. Appl Environ Microbiol 62 3922-3928

Simon M. Alldredge AL, Azam F (1990) Bacterial carbon dynamics on marine snow. Mar Ecol Prog Ser 65:205-211

Smith DC, Simon M, Alldredge AL, Azam F (1992) Intense hydrolytic enzyme activity on marine aggregates and implications for rapid particle dissolution. Nature 359 $139-141$

Stevenson LH (1978) A case for bacterial dormancy in aquatic systems. Microb Ecol 4:127-133

Suzuki MT, Giovannoni SJ (1996) Bias caused by template annealing in the amplification of mixtures of $16 \mathrm{~S}$ rRNA genes by PCR. Appl Environ Microbiol 62:625-630

Walters RA, Cheng RT, Conomos TJ (1985) Time scales of circulation and mixing processes of San Francisco Bay waters. Hydrobiologia 129:13-36

Weiss P, Schweitzer B, Amann R, Simon M (1996) Identification in situ and dynamics of bacteria on limnetic organic aggregates (lake snow). Appl Environ Microbiol 62: 1998-2005

Werner I, Hollibaugh JT (1993) Potamocorbula amurensis comparison of clearance rates and assimilation efficiencies for phytoplankton and bacterioplankton. Limnol Oceanogr 38:949-964

Wienke SM, Cloern JE (1987) The phytoplankton component of the seston in San Francisco Bay. Neth $\mathrm{J}$ Sea Res 21 $25-33$

Yoon WB, Rosson R (1990) Improved method of enumeration of attached bacteria for study of fluctuation in the abundance of attached and free-living bacteria in response to diel variation is seawater turbidity. Appl Environ Microbiol 56:595-600

Submitted: June 8, 1999; Accepted: September 10, 1999 Proofs received from author(s): February 17, 2000 